\title{
A Probe into the Optimization Strategy of the Ethical Education Path of Contemporary College Students' Self-employment
}

\author{
LyuJian Qian*, Tingting Gu \\ Chongqing University of Arts and Sciences, Chongqing 402160, China \\ Email: 31525239@qq.com
}

\begin{abstract}
Mass entrepreneurship and innovation" is put forward to revitalize the economy so as to relieve the pressure in social employment, enhance the development of new driving force, promote national economic development, which is an important way to achieve national prosperity and people's prosperity. As members of the society, contemporary college students should be the participants and practitioners of "mass entrepreneurship and innovation". The ethical education in independent business should be conducted from the following aspects: honesty based education, responsibility based education, justice and benefit based education, professional ethics based education, competition and cooperation based education and education of will, which can be achieved with joint efforts of universities, families, government and society.
\end{abstract}

Keywords: college students, self-employment, ethical education

Against the background of economic globalization, informationization and knowledge, independent entrepreneurship has become the goal prioritized by many college students. However, there lacks adequate focus current focus of college students on self-employment ethics based education, rather college students are characterized with material utility. The setting of curriculum is unreasonable and the ethical education of teachers is not professional. Self-employment based ethics failed to form resultant force. College students show lack of ethical quality. The lack of self-employment based ethical education is not conducive to the cultivation of college students' professional quality and the improvement of their competitive ability, which also hinders the sustainable development of college students' self-employment. Therefore, it has become a new task to study the ethical education of college students' self-employment.

\section{The self-employment of contemporary college students conforms to the development trend of the times}

College students are the subjects of knowledge creation and scientific and technological innovation in the future. Cultivating innovation on innovation and entrepreneurship ability is not only the realistic demand of social development, but also the requirement of the times for building an innovation-oriented country ${ }^{[1]}$. With the development of popularization of higher education and the expansion of college enrollment, the number of college graduates is increasing, and the employment situation is becoming increasingly severe year by year. In 2019, the number of college graduates across the country has increased by 140, 000 compared with that in 2018, reaching 8.34 million $^{[2]}$. Combined with the former graduates who failed to find a job in previous years and students who have returned from studying abroad, about 10 million college students are facing job competition. How to effectively solve the employment of college students has become an urgent task. Mass entrepreneurship and innovation is a huge driving force for economic and social development. The choice of college students to start their own businesses will relieve the employment pressure of the society, expand employment opportunities, but also fully stimulate the wisdom and creativity of the majority of students, become an important force for the steady economic growth.

\section{The meaning and significance of significance of the ethical education of contemporary college students in self-employment}

Ethics is the moral principles and norms that people in society should abide by. The self-employment of college students cannot be separated from the guidance of these moral principles and moral codes. Ethical education is a practical rational cognition and judgment education, and a practical action education that includes "personal conduct, professional ethics, social responsibility, legal concept, healthy psychology and many other aspects of entrepreneurs"[3]. In terms of educational practice, ethical education refers to the planned and purposeful cultivation of college students' self-entrepreneurship spirit in the cultivation of their self-entrepreneurship consciousness and ability, so as to form the will to struggle for the ideal, 
and to be full of strong creativity in the process of self-entrepreneurship, thus laying a foundation for the success of selfentrepreneurship. Specifically, college students' self-employment ethical education is the process of self-employment ideal faith education of college students, which changes the college students' employment concept, self-employment actively, to their own professional knowledge, skills and interest in specialty, the individual needs and social needs and individual ideal and social development, In the process of self-employment, both self-value and social value can be realized, and the dialectical unity of personal value and social value can be realized. College students are a special social group. They are a group with relatively high knowledge and intelligence. Through learning professional knowledge in various fields, they have developed strong professional ability. At the same time, college students are a dynamic and passionate group, they are willing to contact and accept new things. Self-employment based ethical education of college students can, to a great extent, promote the competitiveness of college students in self-employment market, enhance the participation spirit of college students for self-employment, strong will to overcome the difficulty as a result, they dare to struggle of quality, integritybased business philosophy, stick to justice sentiment, the courage to bear the social responsibility, contributing to society, the spirit of solidarity and collaboration, etc.

\section{Analysis of the ethical education path of self-employment of contemporary college students}

In order to achieve practical results, it is necessary to establish scientific ethical education concept, perfect the content system, and give play to the resultant forces of school, family, government and school.

\subsection{Establishing the scientific concept of college students' self-employment ethics based education}

Idea is the external representation of the inner nature of things and plays a leading role in the development of things. The scientific idea of ethical education of college students in self-employment should be targeted for the all-round development of college students and the healthy and sustainable development of self-employment, so that college students can form the values of ethical education of self-employment. Integrating educational resources and organically combine school education, internship education and extracurricular practice education, so that college students can consciously practice professional ethics and become talents needed by the society.

\subsection{Improving the content system of college students in self-employment ethical education}

The content system is the core part of the ethical education of college students' self-employment. The content system should be targeted, including honesty education, responsibility education, justice and interests education, professional ethical education, competition and cooperation education, faith and will education, etc.

\subsubsection{Integrity education}

Integrity is a good virtue. Integrity is built on the unity of justice and interests, which is the basis of human life. Integrity is the prerequisite for college students to realize their legitimate rights and interests in self-employment, as well as the inevitable requirement and moral code of market economy development. Taking integrity as the core content of college students' self-employment ethical education is an important guarantee for college students to realize their life value.

\subsubsection{Responsibility education}

Responsibility education belongs to the category of ethics, which refers to "norms of social behavior jointly formulated and observed by members of the society in order to maintain the reasonable order due to the society, as well as moral beliefs arising therefrom"[4]. Responsibility education is also called right and compulsory education. Rights and obligations are interrelated and unified in opposites. There are no rights without obligations, and there are no obligations without rights. The formation of a person's concept of responsibility will undergo a relatively long process from consciousness cultivation to ideal establishment. Therefore, responsibility education should be carried out to college students from such aspects as the cultivation of responsibility consciousness, the establishment of responsibility view, the cultivation of responsibility quality and the affirming of responsibility ideal. In this way, college students can not only enjoy the rights granted by the state and society, but also fulfill their due obligations in the future self-employment, and form the concepts and abilities of self-responsibility, responsibility of others, professional responsibility and social responsibility.

\subsubsection{Education on the concept of morality and interests}

The concept of morality and interests refers to people's views on the relationship between ethics and material interests. "morality" mainly includes justice and loyalty. "Interests" refers to material interests and utility. The concept of justice and interests is the concrete embodiment of the world outlook, outlook on life and values. The education of the concept of justice and interests can enable college students to establish a scientific consciousness of "three views", which will guide them to form the correct concepts and thoughts of "unity of morality and interests" and "morality before interests" in the process of 
starting their own businesses.

\subsubsection{Professional ethics based education}

Professional ethics is the code of conduct and the system of moral norms of people who are engaged in a certain profession. In the ethical education of college students' self-employment, it is necessary to strengthen the professional ethics based education of honesty and trustworthiness, devotion to work, justice and serving the masses and contributing to the society. To guide and educate college students to show passion to their own work and respect for their own career in the process of self-employment so as to work honestly, keep their promises and strive for credibility in a legal manner. Openness, fairness and justice, principles and impartiality should be the norms for routine work and the unhealthy practices of in the industry should be resisted to establish a good image. More efforts can be made to strive to contribute to the society etc.

\subsubsection{Competition and cooperation based education}

Competition is rivalry with others or other groups for the benefit of oneself or the group. Cooperation is the mutual cooperation or joint behavior between oneself and others, the group and other groups to achieve the common purpose. Cooperation is made based on competition, and cooperation is driven by competition. Competition and cooperation are dialectical relations of mutual dependence, mutual promotion and mutual unity. In the behavior of socialist market economy, college students' self-employment must follow the principle of competition and cooperation, cooperation in competition and development by cooperation.

\subsubsection{Faith and will based education}

Faith and will is the key to the success of college students' self-employment. According to the age and psychological characteristics of college students, faith education, frustration education and self-adjustment education should be taken as the main content, and subjective initiative should be brought into play to achieve the unity of "Heteronomy" and "Selfdiscipline", the unity of "knowledge" and "action", and to adhere to the unity of "self-respect", "introspection" and "selfexcitation", so that one can always be with full enthusiasm and fighting spirit for the cause of self-employment.

\subsection{Formation of the resultant force of ethical education among college students}

\subsubsection{Giving full play to the main role of colleges and universities}

Colleges and universities should strengthen the concept of college students' self-employment, adhere to the peopleoriented approach, cultivate the positive attitude, skills and indomitable will quality of college students' self-employment, and fully explore the potential of students' personality. From the perspective of ethics, the education of college students' self-employment is not only made to cultivate college students' self-employment consciousness, spirit, ability and innovation consciousness, but also involves the moral education of ethical spirit and ethical value orientation. Therefore, the employment ethical education of college students should take the people as the center and carry out the idea of human nature to the best, which embodies the humanistic spirit and value idea of ethical care. Therefore, the ethical education of self-employment should be carried out. Firstly, on the basis of self-employment skills education, the guidance and education of self-employment ethics should be strengthened. Second, to strengthen the belief education of college students in selfemployment. College students can rationally treat and make rational choices in the face of various setbacks and gradually establish correct moral concepts. Thirdly, the guidance course of self-employment should be taken as the main course of self-employment ethical education and infiltrated into other disciplines. Fourth, to cultivate a group of scholars and experts to guide the work of self-employment, improve the level of self-employment ethical education, so that the education of selfemployment ethics of college students is standardized and professional.

\subsubsection{Active involvement of family members}

The family is the first school in the growth of each college student. The emotional understanding, value orientation and employment attitude of college students are often influenced by the family environment and are deeply influenced by it. Family plays a key role in stimulating the motivation of college students to start their own businesses, and parents' views and attitudes towards self-employment will indirectly affect the choice of college students to start their own businesses. Family participation in self-employment based ethical education for college students refers to the following two aspects: The first is that parents should actively cultivate their children's quality in independence and self-improvement. Parents should always pay attention to the situation of college students, including not only the study and life of the children, but also their ideological dynamics, psychological conditions and moral qualities, as well as hard-working, thrifty behavior habits and to consciously cultivate their ability to take care of themselves and encourage them to participate in social practice. The second is to change their attitude towards their children's career choice. It has always been the common wish of parents who "wish their sons can dragons and their daughter to be a phoenix". With the development of society, parents should keep pace with the times and change the concept of employment and career choice and the attitude towards self-employment. When children 
choose to start their own businesses, they should be respected, encouraged and supported.

\subsubsection{Ethical support of government policies}

The government's policy in ethical concern reflects the government's attention to the development of college students' self-employment, which embodies the government's ethical feelings, value input and measures and it is also the standard of the policy and system issued by the country to ensure the smooth development of college graduates' self-employment. Preferential policies and service system play a supportive role in the smooth progress of college students' self-employment. The government should give full play to its functions, improve the content of college students' self-employment, timely disclose various service information and preferential policies, establish a sound service system, and strengthen the strength of support. At present, the state and governments at all levels have issued many preferential policies concerning financing, business opening, taxation, entrepreneurship training and entrepreneurship guidance. For example, the Notice on Tax Policies for Supporting and Promoting Employment clearly states that graduates who start their own businesses can enjoy three years of tax exemption and exemption from tax in the year of graduation.

\subsubsection{Social environment should be made with highlight on ethical concern}

As a social group, the social environment is an indispensable external factor for college students to start their own business, which directly affects their attitude, value orientation, life style and so on. At the same time, good moral environment and correct value orientation can improve the effect of ethical education of college students' self-employment. The effectiveness of the ethical education of college students' self-employment cannot be separated from the ethical concern of social environment. Therefore, Therefore, it is necessary to optimize the social environment to guide college students to form a scientific ethical concept of job selection, which put forward the requirements for the society to play a correct role of value guidance, and the concept of success should be updated to encourage, care and support college students to have the courage to start their own businesses without fear of failure, rather to tolerate failure. As a result, a good atmosphere of ethical care can be developed for college students to start their own businesses.

\section{References}

[1] Li Liping. The Optimization Strategy of College Students in Innovation and Entrepreneurship Based Education Path[J]. The Party Building and Ideological Education in Schools, 2016 (16): 84-86.

[2] Zhang Jiongqiang. New hing in the number of college graduates in 2019, Eastday. com, December 18, 2018. http://edu. eastday. com/node2/jypd/n5/20181218/u1ai18981.html.

[3] $\mathrm{Hu}$ Bo. Analysis of Moral Education for College Students in Entrepreneurship from the Perspective of Ethics[J]. Education Modernization, 2017 (24): 22-23.

[4] Su Jie. Dilemma and Solution in Professional ethical education from the Perspective of Cultural Consciousness Among College Students[J]. The Party Building and Ideological Education in Schools, 2018 (11): 69-71. 